PUSTABIBLIA: Journal of Library and Information Science

ISSN 2549-3493 (Print); ISSN 2549-3868 (Online)

DOI: http://dx.doi.org/10.18326/pustabiblia.v5i2.245-274

SK Dirjen Risbang-Kemristekdikti No 23/E/KPT/2019 (Peringkat 4 SINTA)

\title{
Pelaksanaan Knowledge Management dalam Tata Kelola Jurnal Pustaka Ilmiah Universitas Sebelas Maret Surakarta
}

\author{
Sri Junandi ${ }^{1}$, Haryanto ${ }^{2}$ \\ ${ }^{1}$ Perpustakaan Universitas Gadjah Mada Yogyakarta \\ ${ }^{2}$ Perpustakaan Universitas Sebelas Maret Surakarta \\ Email: s_junandi@ugm.ac.id
}

Naskah diterima: 04-11-2021, direvisi: 16-11-2021, disetujui: 17-11-2021

\begin{abstract}
This study aims to: describe the practice of implementing knowledge management in the management of the Jurnal Pustaka Ilmiah Journal, and to find out what activities are oriented towards increasing the culture of sharing knowledge in the management of the Jurnal Pustaka Ilmiah Journal. This research is a descriptive qualitative research. Data collection was carried out using interview, observation, and documentation methods. The informants in this study were the managers of the current and previous Jurnal Pustaka Ilmiah Journal, amounting to 4 people. The data analysis technique used is the Miles and Huberman technique. The data is presented in a narrative format and equipped with supporting pictures in several parts. The findings of this study are that Jurnal Pustaka Ilmiah Journal's human resources was still very limited, but have a strong commitment. Jurnal Pustaka Ilmiah Journal was led by an egalitarian leadership style. Communication between managers is carried out over various media both synchronously and asynchronously. Institutions play a role in providing material-immaterial support in this matter even though the intensity is still limited to ceremonial. Meanwhile, the learning process in managing Jurnal Pustaka Ilmiah Journal found that managers did not hesitate to try new things to improve the quality of journal management. The success of the knowledge transfer process is not the success of the journal manager alone, but rather needs to get support from various elements, such as the participation of parent institutions which is not limited to ceremonial to create a strong and professional management. This will have implications for increasing the confidence of readers and writers in Jurnal Pustaka Ilmiah as a credible reference in the field of library and information sciences.
\end{abstract}




\begin{abstract}
Abstrak
Penelitian ini bertujuan mendeskripsikan pelaksanaan knowledge management (transfer pengetahuan) tata kelola Jurnal Pustaka Ilmiah, dan mengetahui apa saja kegiatan yang berorientasi pada peningkatan iklim berbagi pengetahuan. Penelitian ini menggunakan penelitian kualitatif deskriptif. Pengumpulan data dilakukan dengan wawancara tidak terstruktur, observasi partisipatif, dan dokumentasi. Informan dalam penelitian ini adalah pengelola Jurnal Pustaka Ilmiah berjumlah 4 orang. Teknik analisis data yang digunakan yaitu teknik Miles and Huberman. Data kemudian disajikan dalam narasi dan dilengkapi dengan gambar pendukung pada beberapa bagian. Temuan diperoleh bahwa Jurnal Pustaka Ilmiah UPT Perpustakaan UNS memiliki jumlah sumberdaya manusia yang cukup kompeten dan memiliki komitmen yang kuat di bidang pengelolaan informasi knowledge management. Jurnal Pustaka Ilmiah dikelola dengan gaya kepemimpinan yang egaliter. Komunikasi dilakukan melalui berbagai media baik secara synchronous maupun asynchronous. Institusi berperan memberikan dukungan material-immaterial melalui alokasi anggaran serta arahan pimpinan dalam setiap penerbitan. Proses pembelajaran pengelolaan menunjukkan bahwa pengelola berkomitmen tinggi mencoba hal baru menuju kualitas tata kelola jurnal yang kredibel. Keberhasilan proses transfer pengetahuan bukan hanya peran dominan pengelola, tetapi juga dukungan berbagai elemen untuk mewujudkan tata kelola jurnal yang solid dan profesional. Hal tersebut diharapkan akan berimplikasi pada meningkatnya kepercayaan pembaca serta penulis terhadap Jurnal Pustaka Ilmiah sebagai rujukan bidang Ilmu Perpustakaan dan Informasi di Indonesia.
\end{abstract}

Keywords: Jurnal Pustaka Ilmiah; scientific journal; knowledge management; scientific journal management

\title{
1. PENDAHULUAN
}

Publikasi jurnal ilmiah yang berkualitas saat ini menjadi salah satu tolak ukur dari penilaian pada sebuah perguruan tinggi. Hal ini menunjukkan bahwa proses diseminasi hasil-hasil penelitian yang dilakukan oleh civitas akademik berjalan dengan baik. Kedudukan jurnal ilmiah selain sebagai sarana diseminasi hasil penelitian, juga berperan dalam memfasilitasi syaratsyarat kenaikan jabatan fungsional bagi dosen, widyaiswara, guru, peneliti, dan fungsional lainnya. Selain itu jurnal ilmiah juga sebagai wadah bagi 
mahasiswa pascasarjana dan doktor yang diwajibkan untuk menerbitkan publikasi di jurnal ilmiah sebagai syarat kelulusan. Mengingat akan pentingnya peran jurnal ilmiah bagi pengembangan perguruan tinggi maka sejak tahun 2018, pemerintah telah menerbitkan Peraturan Menteri Riset Teknologi dan Pendidikan Tinggi Nomor 9 tahun 2018 tentang akreditasi jurnal ilmiah. Selanjutnya pada tahun 2019 telah dilakukan perubahan struktur organisasi kementerian, dan Kementerian Riset Teknologi/Badan Riset dan Inovasi Nasional ditetapkan sebagai pengelola akreditasi jurnal ilmiah melanjutkan pengelolaan yang sebelumnya dilakukan oleh Kementerian Riset, Teknologi, dan Pendidikan Tinggi (Kemenristekdikti). Pemerintah selalu mendorong dan memfasilitasi agar para pengelola jurnal ilmiah untuk meningkatkan tata kelola jurnal sehingga dapat terakreditasi SINTA dan terindeks oleh lembaga pengindeks internasional salah satunya scopus. SINTA dan beberapa lembaga pengindeks lain saat ini menjadi indikator dalam penilaian kinerja suatu publikasi (Saputra, 2020).

Hal tersebut masih menjadi sebuah mimpi yang harus direalisasikan oleh sebagian pengelola jurnal, apalagi untuk meraih peringkat akreditasi, sebagian besar pengelola jurnal masih harus berjuang untuk mempertahankan konsistensi publikasi. Jurnal ilmiah dalam Peraturan Menteri Riset, Teknologi, dan Pendidikan Tinggi Republik Indonesia Nomor 9 tahun 2018 dipahami sebagai "bentuk pemberitaan atau komunikasi yang memuat karya ilmiah dan diterbitkan berjadwal dalam bentuk elektronik dan/atau tercetak" (Kementerian Riset, Teknologi, dan Pendidikan Tinggi, 2018). Dalam pengelolaan perpustakaan jurnal ilmiah dikategorikan dalam terbitan berkala yang artinya terbitan yang secara rutin terbit baik per bulan, tiga bulan, empat bulan dan enam bulan. Salah satu kunci jurnal ilmiah adalah terbit rutin secara berkala dan tepat waktu. Akan tetapi, masalah klasik yang dihadapi pengelola jurnal yaitu ketersediaan naskah yang berdampak keterlambatan terbit, lompat edisi, atau bahkan mati suri.

Berbagai kendala tersebut menjadi permasalahan yang lazim dalam tata kelola jurnal ilmiah di Indonesia. Kendala tersebut juga dialami oleh Jurnal Pustaka Ilmiah. Jurnal Pustaka Ilmiah merupakan jurnal bidang 
ilmu perpustakaan yang mulai diterbitkan tahun 2015. Sesuai data di menu Archives jumlah artikel yang diterbitkan mulai Volume 1 No 1 Desember 2015 sampai dengan Volume 5 No 1 Juni 2019 -sejumlah 10-16 artikel. Jumlah artikel mengalami penurunan pada Volume 5 No 2 Desember 2019 sampai dengan Volume 6 No 2 Desember 2020 yaitu 6-7 artikel. Dinamika jumlah artikel yang diterbitkan ini masih dalam kondisi yang diperbolehkan yaitu minimal 5 artikel. Dalam perjalanannya Jurnal Pustaka Ilmiah telah berhasil terbit selama enam tahun sesuai dengan jadwalnya yaitu dalam setahun terbit dua kali pada bulan Juni dan Desember. Jurnal Pustaka Ilmiah di awal penerbitan dikelola dengan cara konvensional/manual belum secara online. Proses penerimaan, review, editing naskah dilakukan secara cetak. Sejak bulan Oktober 2019 mulai dikelola secara online atau daring yaitu proses penerimaan, review, editing naskah melalui sistem aplikasi Online Journal System (OJS). Pada terbitan tahun 2020 sudah memasuki volume 6 Nomor 2 Desember dengan jumlah naskah 7 artikel.

Keterbatasan sumber daya manusia yang menguasai manajemen penerbitan berdampak pada proses pengelolaan jurnal belum berjalan dengan baik, yaitu desain/tampilan jurnal yang belum informatif, proses bisnis yang belum dijalankan, masih rendahnya tingkat sitasi dan statistik kunjungan. Kendala yang dihadapi yaitu belum berhasil terindeks dalam SINTA dan tata kelola belum sesuai peraturan yang berlaku. Cara mengatasi persoalan dan tips yang dilakukan dapat menjadi acuan bagi pengelola Jurnal Pustaka Ilmiah pada khususnya dan pengelola jurnal ilmiah lain pada umumnya.

Dalam rangka mengatasi permasalahan yang dihadapi pengelola Jurnal Pustaka Ilmiah pada tanggal 11 November 2020 menyelenggarakan assessment /penilaian secara daring untuk persiapan submit akreditasi jurnal ilmiah tahun 2021. Kegiatan assessment dengan mengundang narasumber Ketua Redaksi Berkala Ilmu Perpustakaan dan Informasi yang sudah berpengalaman dan berhasil meraih peringkat SINTA 2 pada tahun 2017. Penilaian dilakukan berdasarkan persyaratan yang harus dipenuhi sesuai Permenristekdikti nomor 9 tahun 2018. Akreditasi jurnal ilmiah terdiri atas 8 (delapan) unsur penilaian, yang merupakan kriteria untuk menentukan 
peringkat dan status akreditasi suatu jurnal ilmiah. Kriteria tersebut meliputi 1) Memuat artikel Ilmiah, 2) Memiliki Dewan editor/penyunting, 3) Melibatkan Reviewer atau Mitra bestari berkualifikasi sesuai bidang ilmu, 4) Menggunakan Bahasa Indonesia dan atau Bahasa PBB , 5) Konsisten Gaya Penulisan dan format penampilan, 6) Dikelola dan diterbitkan secara daring, 7) Terbit sesuai jadwal atau on time, dan 8) Memiliki ISSN online dan Digital Object Identifier (DOI) (Kementerian Riset, Teknologi, dan Pendidikan Tinggi, 2018). Pengetahuan menjadi kunci dari suksesnya pengelolaan organisasi (Prabowo, 2020, p. 18). Mustahil dalam pengelolaan jurnal ilmiah tanpa adanya transfer pengetahuan dari pengelola jurnal kepada anggota redaksinya lainnya. Tidak hanya transfer pengetahuan yang sifatnya satu arah. Kebiasaan berbagi pengetahuan perlu dirumuskan agar menjadi budaya organisasi sehingga tidak akan terjadi hanya pada satu atau dua kali saja.

Penelitian ini dilakukan untuk mendeskripsikan realitas praktik manajemen pengetahuan dari pengelolaan Jurnal Pustaka Ilmiah serta praktik baik untuk meningkatkan kesadaran berbagi pengetahuan di antara para anggota pengelolanya. Hasil penelitian ini akan menjadi bahan evaluasi bagi pengelola Jurnal Pustaka Ilmiah untuk menyusun Standar Operasional Prosedur (SOP) dalam tata kelola jurnal yang profesional.

\section{TINJAUAN PUSTAKA}

Penelitian yang menghubungkan tentang manajemen pengetahuan dengan tata kelola jurnal ilmiah pada dasarnya belum terlalu banyak diteliti. Kebanyakan penelitian yang telah menjelaskan secara terpisah bagaimana implementasi manajemen pengetahuan dan strategi tata kelola jurnal. Penelitian pertama dilakukan oleh Prabowo (2020) dengan judul Penerapan Manajemen Pengetahuan dalam Pengelolaan Dokumen di Perpustakaan STIKes Guna Bangsa. Penelitian kualitatif tersebut menekankan manajemen pengetahuan dari aspek pengelolaan dokumen cetak yang sifatnya tangible. Berbeda dengan penelitian ini yang menekankan pada aspek pengetahuan intangible. Penelitian kedua dilakukan oleh Fathurrahmi (2016) dengan judul Manajemen Pengetahuan Jurnal Ilmiah Berbasis Ontologi pada Portal Web 
Semantik). Penelitian pengembangan yang bertujuan untuk membangun sistem manajemen pengetahuan dengan konsep pemetaan ontologi yang dapat mengakomodasi kaitan-kaitan persepsi pada sebuah objek dengan domain berupa e-journal yang kemudian diintegrasikan pada portal web semantik sebagai media pencarian jurnal. Fokus pada penelitian tersebut adalah pada teknologi manajemen pengetahuan. Penelitian ketiga adalah penelitian yang dilakukan oleh Junandi (2018) dengan judul Pengelolaan Jurnal Elektronik Bidang Perpustakaan Menuju Jurnal Terakreditasi. Penelitian kualitatif tersebut menjelaskan praktik baik dari pengelolaan jurnal ilmiah Berkala Ilmu Perpustakaan dan Informasi UGM sehingga memperoleh peringkat SINTA 2. Praktik manajemen pengetahuan telah dilakukan dengan baik dan telah berhasil lolos akreditasi jurnal nasional, meskipun tidak tertulis secara eksplisit.

Penelitian manajemen pengetahuan ini akan menjadi fokus utama sehingga dapat memperkaya apa yang sudah dituliskan pada penelitian sebelumnya. Hal yang dapat didiskusikan kemudian adalah mengetahui kendala proses transfer pengetahuan sejak 2015 sampai dengan sekarang. Sejak 2015 sampai dengan saat ini terjadi transisi teknologi besar-besaran terutama sejak munculnya gawai pintar (smart phone). Transisi teknologi tersebut memungkinkan akan menghasilkan temuan penelitian yang menarik. Selain itu, penelitian ini juga memotret praktik baik dari pengelola Jurnal Pustaka Ilmiah di tengah dinamika transfer pengetahuan yang terkadang mulus dan tidak menemui masalah dan tantangan. Penelitian ini tidak hanya fokus pada pengelolaan jurnal secara teknis, akan tetapi mengungkap hal yang lebih substansial yaitu manajemen pengetahuan yang menjadi fondasi bagi para pengelola jurnal dalam melakukan tugas.

Sebelum membahas manajemen pengetahuan, dalam tinjauan pustaka ini akan diuraikan terlebih dahulu terkait tata kelola jurnal sebagai sebuah siklus komunikasi ilmiah, terutama masifnya era penggunaan Open Journal System (OJS). Pada Gambar 1 adalah tahapan penerbitan jurnal ilmiah melalui OJS. Beberapa tahapan umumnya antara lain: antrian submit naskah, review, editing, manajemen terbitan, publikasi, dan penerbitan isu terbaru. 
OJS Editorial and Publishing Process

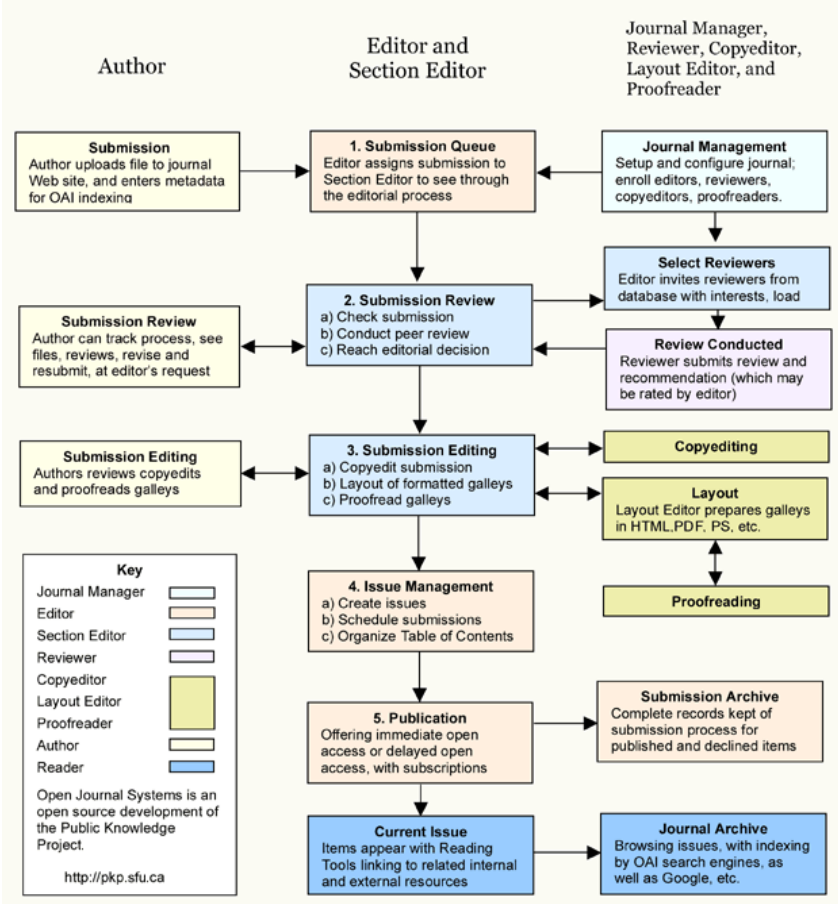

Gambar 1. OJS Editorial and Publishing Process

Sumber: (Public Knowledge Project, 2021)

Manajemen pengetahuan dapat dikatakan sebagai langkah-langkah yang sistematis untuk mengelola pengetahuan dan berbagai informasi baik individu maupun organisasi guna menciptakan keunggulan dan memaksimalkan nilai tambah dan inovasi. Manajemen pengetahuan menemukan urgensinya, terutama di tengah-tengah arus globalisasi yang menekan setiap organisasi untuk terus bergerak dan berbenah (Wiratningsih, 2014)information managers, knowledge managers, and as a place of lifelong learning to prepare human resource competitiveness in the AFTA in 2015? The library is a medium for transfer of knowledge and libraries have contributed to the development of knowledge process. Knowledge is power, organizations that succeed in knowledge management, view of knowledge as an asset in shaping the strength of competitiveness in the global era. Through this simple 
article, the author intends to describe the implementation of the librarian's role in the management of knowledge and information literacy activities in welcoming AFTA 2015. The roles of the library are through the concept of knowledge management through the process of SECI (Socialization, Externalization, Combination and Internalization. Manajemen pengetahuan tidak terbatas mengenai hardware dan software (tangible asset, akan tetapi lebih ditekankan pada pengembangan pengetahuan dan kompetensi para staf (intangible asset) agar memicu untuk bisa berinovasi (Praharsi, 2016).

Tujuan pelaksanaan knowledge management untuk meningkatkan dan memperbaiki operasional sebagai sebuah tindakan sistematis untuk mengidentifikasi, mendokumentasikan, dan mendistribusikan segenap jejak pengetahuan yang relevan kepada setiap civitas akademik (Ningsih, 2013). Prabowo (2016) menjelaskan bahwa terdapat lima komponen manajemen pengetahuan, yaitu: manusia, kepemimpinan, teknologi, organisasi, dan pembelajaran. Kelima indikator tersebut yang menjadi acuan untuk mengetahui praktik manajemen pengetahuan dalam penelitian ini. Adapun rincian sub indikator dari kelima tersebut dalam Tabel 1.

Komunikasi dengan berbagai metodenya adalah fondasi dari proses transfer pengetahuan. Komunikasi efektif yang ditandai dengan adanya umpan balik antar para aktor ternyata tidak hanya dapat terjadi dalam situasi formal atau dengan cara verbal saja, melainkan juga dalam situasi informal dan dengan cara nonverbal (Prabowo, 2019; Widuri, 2015)yang salah satunya adalah komunikasi nonverbal. Komunikasi nonverbal menjadi salah satu indikator untuk mengukur penerimaan dalam proses komunikasi efektif. Penelitian ini bertujuan untuk mengukur sejauh mana penerimaan pemustaka dalam proses komunikasi dengan pustakawan STIKes Guna Bangsa Yogyakarta melalui bahasa tubuh yang diperlihatkan. Metode penelitian yang digunakan adalah kuantitatif deskriptif. Yang menjadi populasi adalah seluruh pemustaka perpustakaan STIKes Guna Bangsa Yogyakarta, sedangkan penentuan sampel menggunakan teknik purposif. Sampel dalam penelitian ini berjumlah 90 responden, yang diambil 30 responden dari masing-masing prodi (Ilmu Kebidanan, Ilmu Keperawatan 
dan Analis Kesehatan. Komunikasi efektif sebagai moda transfer pengetahuan tersebut berperan penting dalam keberhasilan pertukaran pengetahuan antar anggota dalam suatu organisasi. Adapun beberapa faktor yang ditopang oleh keterampilan komunikasi untuk mendorong keberhasilan transfer pengetahuan antara lain: motivasi intrinsik, penerimaan pengetahuan, sikap terhadap knowledge sharing, loss of knowledge power, knowledge self-efficacy, dan pengiriman pengetahuan (Utami, 2019). Sebaliknya, indikator yang mengindikasikan terganggunya transfer pengetahuan akan terganggu antara lain: respon balik, iklim organisasi, norma subyektif, normal timbal balik, motivasi introjektif, teknologi informasi, dan motivasi eksternal (Utami, 2019).

\section{Tabel 1. Sub Indikator Implementasi Manajemen Pengetahuan pada Suatu Organisasi}

\begin{tabular}{|c|c|c|}
\hline No & Indikator & Sub Indikator \\
\hline & Manusia & $\begin{array}{l}\text { - Kesempatan bekerja sesuai dengan bidang keahlian } \\
\text { - Kesempatan untuk menyampaikan pendapat }\end{array}$ \\
\hline 2. & Kepemimpinan & $\begin{array}{l}\text { - Kesadaran pimpinan terkait pentingnya berbagi } \\
\text { pengetahuan } \\
\text { - Kesadaran pimpinan untuk membuka ruang berbagi } \\
\text { pengetahuan }\end{array}$ \\
\hline & Teknologi & $\begin{array}{l}\text { - Kemampuan mengoperasikan teknologi untuk berbagi } \\
\text { pengetahuan } \\
\text { - Ketersediaan infrastruktur teknologi untuk berbagi } \\
\text { pengetahuan } \\
\text { - Adanya hak yang sama untuk mengakses teknologi }\end{array}$ \\
\hline & Organisasi & $\begin{array}{l}\text { - Kesadaran institusi untuk mengikuti tren dan } \\
\text { perkembangan yang positif } \\
\text { - Adanya fasilitas yang memadai yang disediakan } \\
\text { institusi untuk mendukung program berbagi } \\
\text { pengetahuan } \\
\text { - Adanya penghargaan yang diberikan institusi kepada } \\
\text { anggota yang berprestasi }\end{array}$ \\
\hline
\end{tabular}




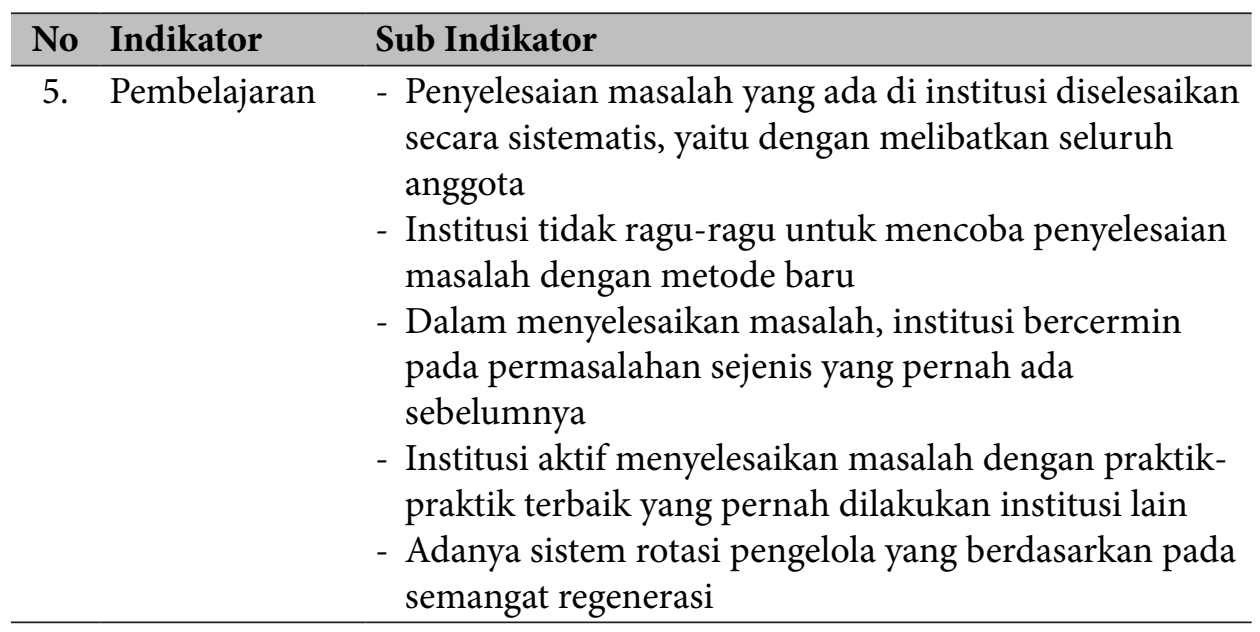

Sumber: Diolah dari Matriks Implementasi Manajemen Pengetahuan Perpustakaan, Prabowo (2016)

Dalam kaitannya dengan manajemen pengetahuan maka konsep ini dapat diimplementasikan dalam sebuah organisasi baik skala mikro maupun makro. Pengelola jurnal ilmiah adalah contoh organisasi mikro ini memerlukan sentuhan dari konsep manajemen pengetahuan. Hal tersebut bertujuan untuk menerapkan pola-pola yang ada sehingga eksistensi publikasi dari sebuah jurnal ilmiah tetap terjaga keberlangsungannya. Pada era digital jurnal ilmiah dituntut untuk bisa dikatakan baik diharuskan memenuhi delapan syarat sesuai dengan Permenristekdikti No 9 Tahun 2018 (Junandi \& Prabowo, 2019).

Dalam tata kelola jurnal ilmiah pengelola memiliki tujuan jurnal yang dikelolanya untuk bisa terakreditasi dalam SINTA. Berdasarkan pengalaman Jurnal Berkala Ilmu Perpustakaan dan Informasi saat proses akreditasi terdapat beberapa usaha yang dilakukan yaitu: perbaikan tampilan OJS, indeksasi jurnal ke DOAJ, hibah bantuan pengelolaan jurnal 2017, dan finalisasi akreditasi (Junandi, 2018). 


\section{METODE}

Penelitian ini adalah penelitian kualitatif deskriptif. Peneliti meletakkan tata kelola Jurnal Pustaka Ilmiah dalam konteks manajemen pengetahuan sebagai objek penelitian ini. Adapun subjek dari penelitian ini adalah organisasi pengelola Jurnal Pustaka Ilmiah, yaitu pustakawan Universitas Sebelas Maret Surakarta yang terlibat dalam kepengurusan jurnal. Pengumpulan data dilakukan dengan metode wawancara tidak terstruktur kepada beberapa pengelola untuk mendapatkan informasi sebanyakbanyaknya terkait proses kronologi tata kelola jurnal. Informan penelitian ini adalah pengelola jurnal yang masih aktif maupun pernah terlibat sejumlah 4 orang. Pemilihan ini dapat secara objektif karena kedua pihak tersebut yang paling mengerti mengenai tata kelola Jurnal Pustaka Ilmiah. Selain cara wawancara juga digunakan metode observasi partisipatif sebagai bentuk konfirmasi atas hasil wawancara. Terakhir dokumen-dokumen yang berkaitan dengan jurnal ilmiah baik yang berupa dokumen cetak maupun elektronik dijadikan tambahan data sekaligus wujud konfirmasi terhadap data lainnya. Teknik analisis data yang digunakan yaitu teknik Miles and Huberman. Aktivitas dalam analisis data model ini meliputi data reduction, data display, dan conclusion drawing/verification. Temuan-temuan yang diperoleh kemudian disandingkan dengan fakta-fakta historis dari perjalanan Jurnal Pustaka Ilmiah dari waktu ke waktu sehingga dari penelitian ini akan membentuk pola yang terkonstruksi dari data yang ditemukan sekaligus kecocokan waktu.

\section{HASIL DAN PEMBAHASAN}

\section{Sumberdaya manusia UPT Perpustakaan UNS}

Sumberdaya manusia merupakan instrumen utama dalam knowledge management pengelolaan jurnal di perguruan tinggi. Kompetensi sumberdaya manusia sangat dipengaruhi oleh pengalaman serta faktor pendidikan dasar baik formal maupun non formal. Dalam pengelolaan Jurnal, pendidikan formal berperan dalam membaca substansi serta teknik penulisan suatu 
karya ilmiah, sedangkan pendidikan non formal merupakan keahlian seperti ICT yang diperoleh dari diklat, kursus, dan sebagainya. Dalam knowledge management pengelolaan jurnal ilmiah terjadi transfer pengetahuan baik antara pengelola serta stakeholder lain. Kelancaran dalam sebuah transfer pengetahuan sangat dipengaruhi oleh berbagai faktor di atas. Sebagai Unit Pelaksana Teknis (UPT) PerpustakaanUNS merupakan gabungan dari berbagai perpustakaan fakultas dan pascasarjana dengan jumlah pustakawan dengan latar belakang pendidikan (S2) 13 orang (S1) 4 orang dan (Diploma) 13 orang. Menurut wawancara dengan tim pengelola pada tangga 15 maret 2021, jumlah tersebut dirasa cukup dalam melaksanakan berbagai kegiatan operasional kegiatan perpustakaan namun terus diupayakan untuk peningkatan kuantitas maupun kualitas pustakawan.

Pengembangan kompetensi sumberdaya manusia di berbagai bidang telah dilakukan oleh tim manajemen Perpustakaan UNS, tidak terkecuali di bidang pengelolaan jurnal ilmiah. Kegiatan tersebut berupa diskusi dalam workshop dengan tenaga ahli yang kompeten di bidang Jurnal Ilmiah. seperti yang telah dilaksanakan dengan tenaga ahli dari Jurnal "Berkala Ilmu Perpustakaan dan Informasi” Universitas Gadjah Mada, hal ini bertujuan agar Jurnal Pustaka Ilmiah bisa tetap eksis dan berkembang sehingga dapat menjadi sebagai salah satu media yang berkontribusi dalam transfer pengetahuan dengan stakeholdernya sampai saat ini.

Kondisi terbaru Jurnal Pustaka Ilmiah

Pembahasan dalam penelitian ini, yaitu menjawab persoalan yang dirumuskan dalam rumusan masalah. Namun sebelum menguraikan permasalahan penelitian, pemaparan mengenai kondisi terbaru dari Jurnal Pustaka Ilmiah juga diperlukan untuk memberikan pemahaman yang menyeluruh. 


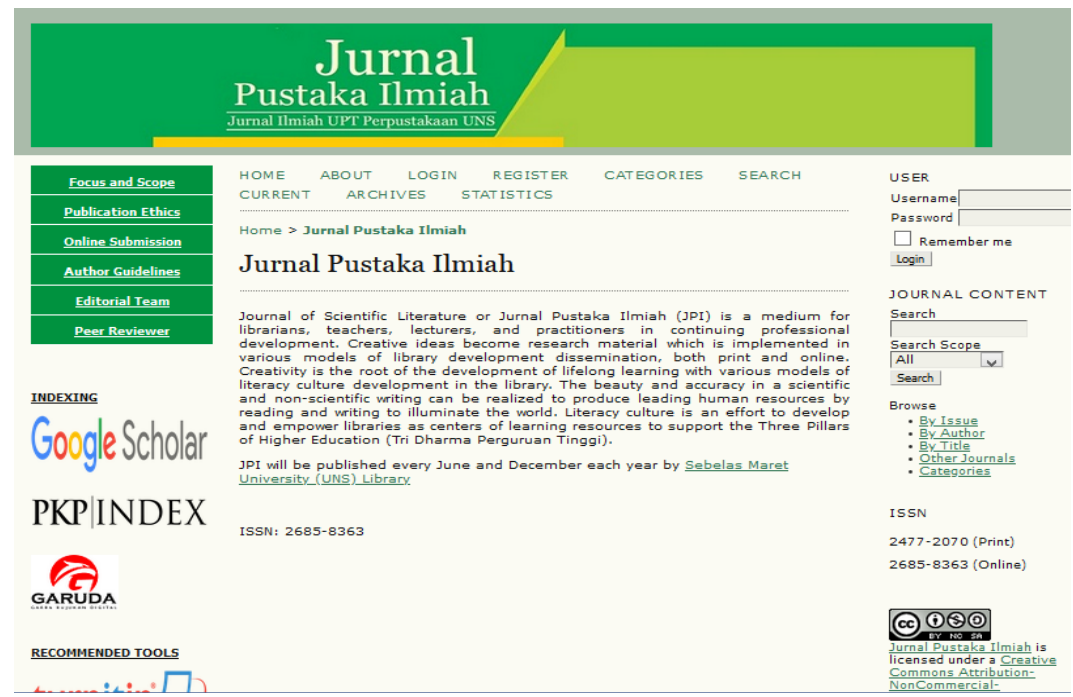

Gambar 2. Portal Open Journal System (OJS) Jurnal Pustaka Ilmiah Sumber: https://jurnal.uns.ac.id/jurnalpustakailmiah (2021)

Sejak bulan Oktober tahun 2019, tata kelola Jurnal Pustaka Ilmiah mulai menggunakan platform Open Journal System (OJS). OJS merupakan sistem manajemen berbasis web yang mendukung untuk penanganan manajemen kegiatan publikasi jurnal dalam bentuk online, dalam sistem ini kegiatan seperti call for article, submission, review, editing, dan publikasi dilakukan secara online. Dengan menggunakan sistem ini, selain produk cetak, Jurnal Pustaka Ilmiah telah bertransformasi menjadi jurnal dalam bentuk elektronik. Tahap awal penerapan sistem OJS masih sekadar media untuk mengunggah file bertipe .pdf dari jurnal. Adapun, proses seperti call for article, submission, review belum menggunakan sistem OJS. Namun pada rencana perkembangannya, beberapa kegiatan tersebut akan dilakukan menggunakan OJS secara penuh.

Selanjutnya, dalam upaya mendukung identifikasi terbitan Jurnal Pustaka Ilmiah dalam bentuk elektronik dilakukan pengajuan E-ISSN (Electronic International Standard Serial Number) pada bulan Agustus 2019. Sebelumnya jurnal ini telah mendapatkan ISSN print tahun 2015 dengan 
nomor 2477-2070. Proses pengajuan E-ISSN dilakukan secara online melalui web http://issn.pdii.lipi.go.id/ dengan melakukan registrasi dan mengunggah persyaratan administratif. E-ISSN diperoleh pada 16 Agustus 2019 dan mulai berlaku untuk edisi Volume 5 Nomor 2 Desember 2019. Terbitan pertama Jurnal Pustaka Ilmiah sejak tata kelola dengan OJS adalah volume 5 nomor 2 bulan Desember tahun 2019. Pada nomor tersebut terbit enam artikel dengan satu penulis internal dan lima penulis eksternal yang berasal dari berbagai latar belakang. Untuk penulis internal pengelola berkomunikasi secara verbal karena hampir bisa dipastikan bertemu setiap hari karena pekerjaan di perpustakaan. Penulis eksternal merupakan relasi atau kolega dari para pengelola Jurnal Pustaka Ilmiah, komunikasi yang dilakukan untuk penjaringan artikel tersebut juga berlangsung secara informal melalui media instant messenger seperti WhatsApp.

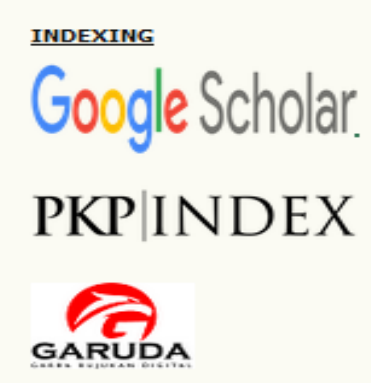

Gambar 3. Lembaga Pengindeks Jurnal Pustaka Ilmiah

Sumber: https://jurnal.uns.ac.id/jurnalpustakailmiah (2021)

Sejak diterapkannya sistem tata kelola jurnal dengan OJS, Jurnal Pustaka Ilmiah berorientasi agar artikel yang terbit bisa terindeks oleh lembaga pengindeks. Saat ini Jurnal Pustaka Ilmiah sudah terindeks oleh Google Scholar, GARUDA, dan PKP/Index. Adapun untuk dapat diindeks oleh SINTA, Jurnal Pustaka Ilmiah masih memerlukan perbaikan dan pembenahan sesuai hasil assesment yaitu 1) pernyataan sebagai jurnal ilmiah belum sesuai platform, 2) link terkait ISSN online dan print belum ada, 3) 
informasi terkait histori jurnal belum dicantumkan, 4) belum melibatkan editor eksternal dan data curriculum vitae (CV) dan profil google scholar (GS) belum dicantumkan, 5) belum semua data CV dan profil GS mitra bestari dicantumkan, 6) petunjuk penulisan (author guidelines) tidak konsisten dengan bahasa pengantar, 7) belum adanya saran penggunaan aplikasi referensi, 8) statistik akses kunjungan yang tidak aktif, 9) belum adanya informasi judul sirahan pada artikel yang diterbitkan. 10) sistem penomoran halaman masih melanjutkan volume sebelumnya, 11) proses bisnis belum dijalankan dengan baik, 12) dampak ilmiah atau sitasi di profil GS jurnal belum up to date, 13) informasi terkait kebijakan review process belum dicantumkan, dan 14) keterangan distribusi afiliasi penulis belum dicantumkan.

Sebagai tindak lanjut hasil assesment tersebut di atas, pengelola Jurnal Pustaka Ilmiah harus melakukan upaya perbaikan dan pembenahan terkait tata kelola jurnal agar dalam proses submit akreditasi mendapatkan peringkat SINTA yang optimal.

\section{1) Pernyataan sebagai jurnal ilmiah belum sesuai platform}

Pernyataan sebagai jurnal ilmiah yang memuat bahwa artikel yang dimuat berasal dari hasil penelitian atau kajian yang telah melalui proses review secara single blind maupun double blind perlu dipertegas. Dalam memperbaiki pernyataan sebagai jurnal ilmiah pengelola Jurnal Pustaka Ilmiah dapat menggunakan platform jurnal nasional yang sudah berhasil meraih peringkat SINTA 2, misalnya Jurnal Kajian Informasi dan Perpustakaan (JKIP) yang diterbitkan Fakultas Ilmu Komunikasi Universitas Padjadjaran Bandung seperti tercantum dalam gambar 4. 


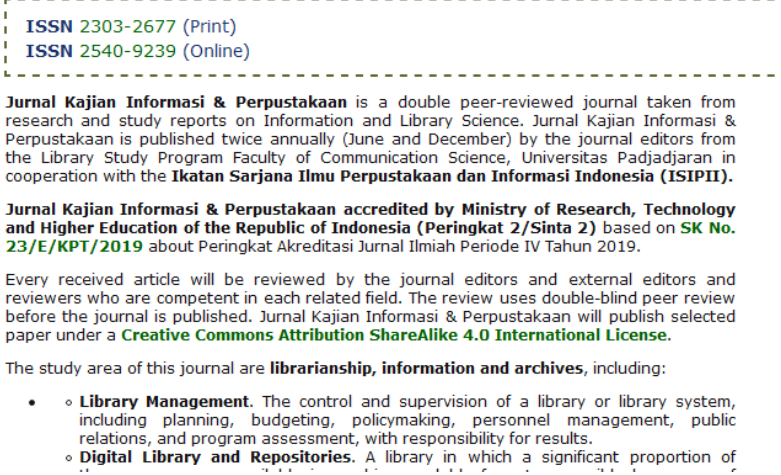

Gambar 4. Pernyataan sebagai jurnal ilmiah yang sesuai platform Sumber: http://jurnal.unpad.ac.id/jkip/index (2021)

\section{2) Link terkait ISSN elektronik dan print belum ada}

Informasi tentang ISSN print dan online yang dimiliki Jurnal Pustaka Ilmiah belum terhubung dengan Pusat Nasional ISSN Indonesia PDDI LIPI sebagai bukti kepada asesor manajemen waktu proses submit akreditasi. Informasi link ISSN Jurnal Pustaka Ilmiah seperti dalam -Gambar 5.

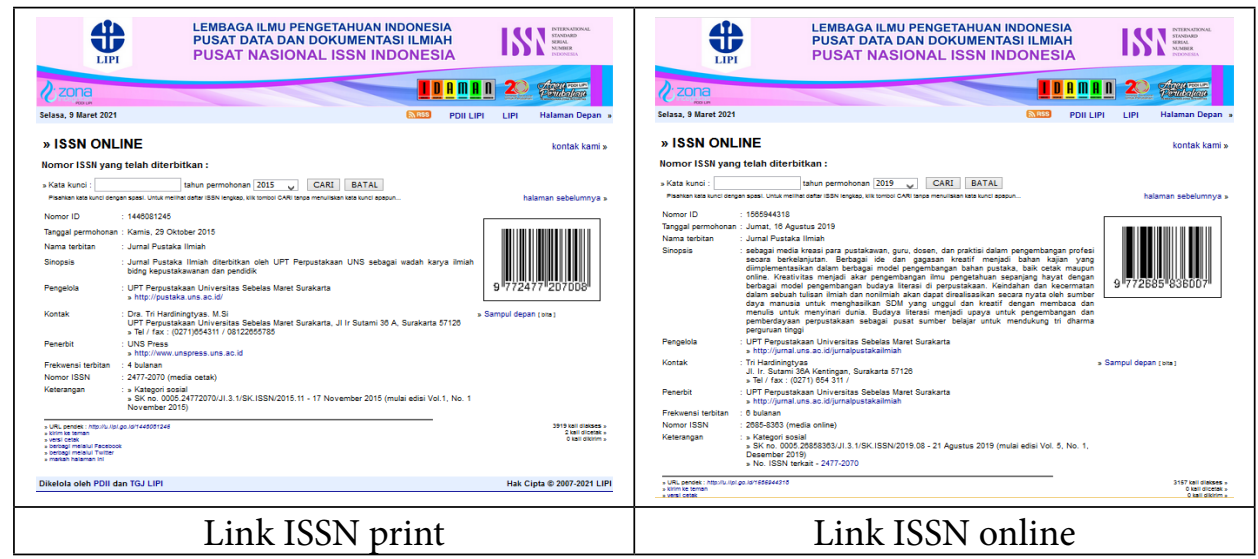

Gambar 5. Link ISSN Jurnal Pustaka Ilmiah print dan online

Sumber: http://u.lipi.go.id/1565944318 (2021) 


\title{
3) Informasi terkait histori jurnal belum dicantumkan
}

Informasi tentang sejarah Jurnal Pustaka Ilmiah, kapan mulai diterbitkan, berafiliasi pada unit atau lembaga apa, latar belakang penerbitan, dan perubahan terkait manajemen jurnal yang telah dilakukan. Informasi terkait histori jurnal dapat menggunakan platform di Jurnal Kajian Informasi dan Perpustakaan (JKIP) yang diterbitkan Fakultas Ilmu Komunikasi Universitas Padjadjaran Bandung yang terindeks SINTA 2 sejak 2019 seperti tercantum dalam -Gambar 6.

e Home > About the Journal > Journal History

\begin{abstract}
Jurnal Kajian Informasi \& Perpustakaan was published in December 2012, by LP3, Faculty of Communication Science, Universitas Padjadjaran. The first printed edition was published in June 2013. Meanwhile, Jurnal Kajian Informasi \& Perpustakaan start using Online Journal System in June 2016. Therefore, our publication from June 2013 until December 2016 was back issued.

Since Vol. 4, No. 2, December 2016 (after obtaining ISSN-Online), Jurnal Kajian Informasi \& Perpustakaan has a change in publisher which was initially published by LP3, Faculty of Communication Science, Padjadjaran University, changed to the Library Science Study Program, Faculty of Communication Science, Padjadjaran University.

Then in 2017, the name of the Journal in the header of the website has changed the conjunction 'and' in Jurnal Kajian Informasi dan Perpustakaan to the logogram ' $\&$ ' thus, it becomes Jurnal Informasi \& Perpustakaan to adjust the data of the original name on the delivery of the ISSN Journal.

On April 26, 2017, Jurnal Kajian Informasi \& Perpustakaan received Training in the Application of the Electronic Journal/O]S Application from the Directorate General of Higher Education, Kemristekdikti. After that, we did some alterations to improve. Authors' guidelines were revised in December 2017 on article interface and header ("judul sirahan").

We also use journal templates for the December 2017 edition with additional titles on the first page and layout settings. Besides, in the same publication, we also revised the focus and scope and made several changes to the ISSN information on the Front Cover and Publisher on the Back Cover.

Then, since the December 2017 edition, we have also implemented a double-blind review along with improvements to the assessment instruments for reviewers.

At 30 June 2019, Dr. Pawit M. Yusup stepped down as Editor-in-Chief. From 1 July 2019, Andri Yanto, M.I.Kom will take over the position of Editor-in-Chief. The review procedure will remain the same as before, and the notification of the decision will be sent by the same address jkip.fikom@unpad.ac.id on behalf of the same Editor-in-Chief address,jkip.fikom@unpad.ac.id.
\end{abstract}

\section{Gambar 6. Pernyataan histori jurnal ilmiah yang sesuai platform}

Sumber: http://jurnal.unpad.ac.id/jkip/index (2021)

4) Belum melibatkan editor eksternal, data curriculum vitae (CV) dan profil google scholar (GS) belum dicantumkan

Dalam struktur dewan penyunting sebaiknya pengelola Jurnal Pustaka Ilmiah melibatkan editor eksternal sebagai representasi sebagai jurnal nasional yang beranggotakan lintas wilayah nasional, berbagai daerah dan lembaga. Struktur dewan penyunting dapat menggunakan jurnal yang 
sudah berhasil terindeks SINTA 2, misalnya Berkala Ilmu Perpustakaan dan Informasi yang diterbitkan oleh Perpustakaan UGM seperti tercantum Gambar 7.

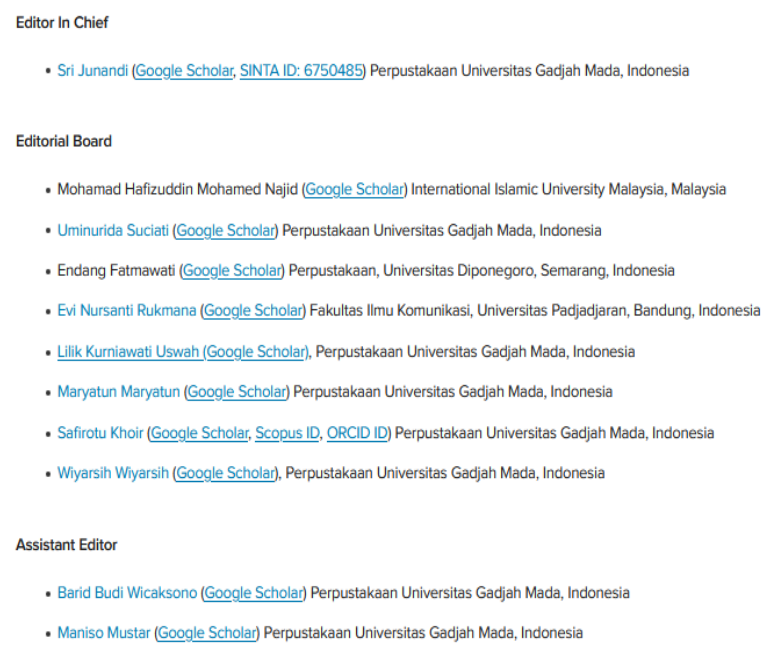

\section{Gambar 7. Struktur dewan penyunting jurnal ilmiah yang sesuai platform \\ Sumber: https://journal.ugm.ac.id/v3/BIP/about/editorialTeam (2021)}

\section{5) Belum semua data CV dan profil GS mitra bestari dicantumkan}

Peran mitra bestari dalam memberikan masukan dan kelayakan naskah yang dikirim oleh author merupakan salah satu persyaratan jurnal ilmiah yang berkualitas. Mitra bestari yang berkualitas secara ketat menjaring naskah, memberikan catatan dan saran perbaikan substantif sehingga focus and scope journal naskah terjaga. Selain itu mitra bestari produktif dalam menghasilkan karya ilmiah sesuai bidang keahliannya yang dibuktikan dalam data CV ataupun profil GS yang dapat diakses secara publik. Oleh karena itu data CV, profil GS, ataupun Scopus ID dicantumkan dengan komprehensif dan lengkap. 


\title{
Peer Reviewers
}

\author{
Agus Rifai (Scopus ID, Google Scholar) Universitas Islam Negeri Syarif Hidayatullah Jakarta, Indonesia \\ Imam Yuadi (Scopus ID, Google Scholar) Universitas Airlangga, Surabaya, Indonesia \\ Riah Wiratningsih (Scopus ID, Google Scholar) Universitas Sebelas Maret Surakarta, Indonesia \\ Edwin Rizal (Scopus ID, Google Scholar) Universitas Padjadjaran, Bandung, Indonesia \\ Agus Rusmana (Scopus ID, Google Scholar) Universitas Padjadjaran, Bandung, Indonesia \\ Jonner Hasugian ( \\ Abdul Rahman Saleh (Google Scholar) Institut Pertanian Bogor, Bogor, Indonesia \\ Sri Hartinah (Google Scholar) Pusat Dokumentasi Informasi IImiah Lembaga IImu Pengetahuan Indonesia (PDII-LIPI), Jakarta, \\ Indonesia \\ Ida Fajar Priyanto (Scopus ID, Goole Scholar) Universitas Gadjah Mada, Yogyakarta, Indonesia \\ Lasa Hs (Google Scholar) Universitas Muhammadiyah Yogyakarta, Indonesia \\ Sulistyo Basuki (Scopus ID, Google Scholar) Universitas Indonesia, Indonesia
}

\section{Gambar 8. Struktur Mitrabesari/Peer Reviewers jurnal ilmiah yang sesuai platform \\ Sumber: https://journal.ugm.ac.id/v3/BIP/people (2021)}

\section{6) Petunjuk penulisan (author guidelines) tidak konsisten dengan bahasa pengantar}

Petunjuk penulisan yang informatif dan jelas akan memberikan dampak kepada penulis taat pada gaya selingkung jurnal. Pengelola jurnal juga memberikan contoh template sehingga penulis dengan mudah mengisi substansinya saja. Oleh karena itu author guidelines Jurnal Pustaka Ilmiah diperbaiki dengan menggunakan bahasa Inggris sesuai platform jurnal ilmiah terakreditasi SINTA 2, misalnya Jurnal Kajian Informasi dan Perpustakaan seperti dalam Gambar 9. 
Author Guidelines

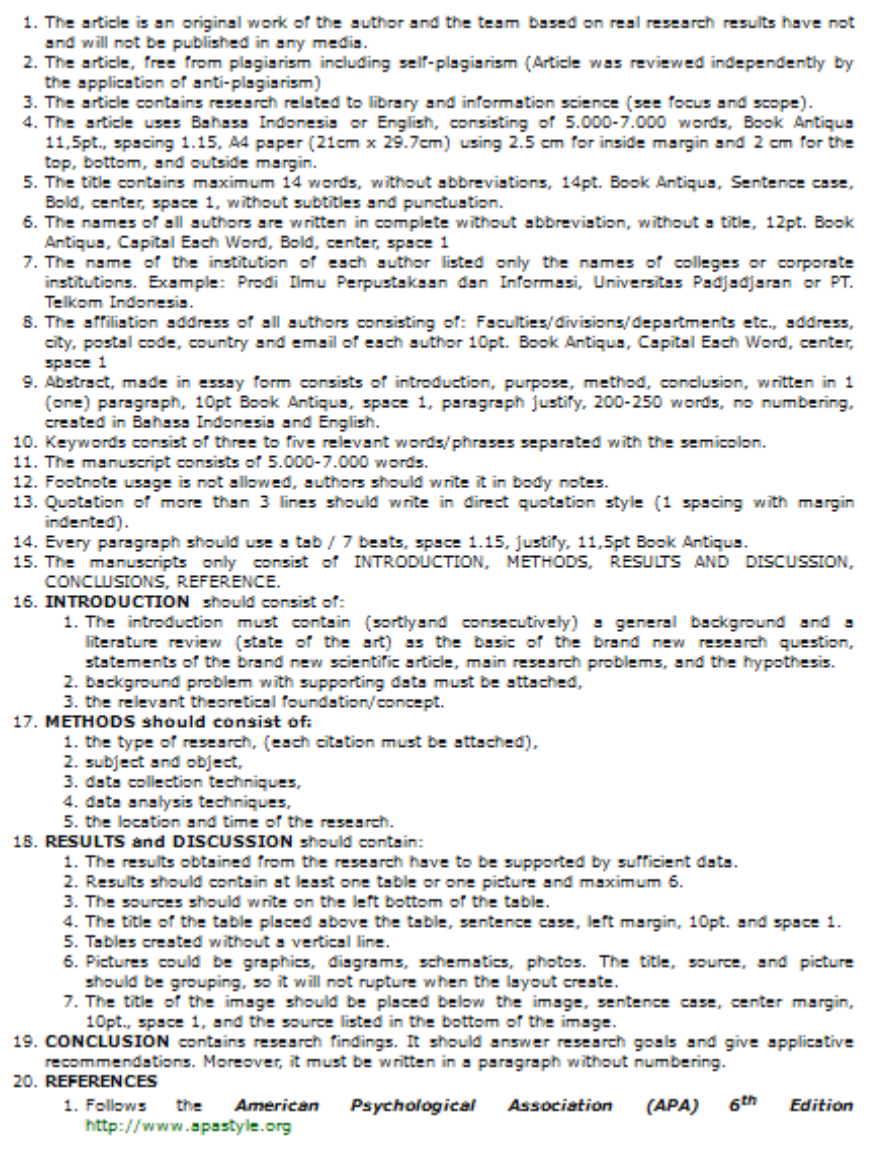

Gambar 9. Petunjuk penulisan jurnal ilmiah yang sesuai platform

Sumber: https://journal.ugm.ac.id/v3/BIP/people (2021)

\section{7) Belum adanya saran penggunaan aplikasi referensi}

Kualitas naskah jurnal ilmiah dapat diukur dengan jumlah daftar pustaka yang diacu atau disitasi dalam badan tulisan ilmiahnya. Tujuan pengutipan daftar pustaka yaitu untuk memperkaya gagasan terkait subjek yang menjadi pokok bahasan dalam artikel. Dalam penulisan daftar pustaka harus mengikuti style atau gaya yang dianut oleh sebuah jurnal 
ilmiah. Dalam meminimalisir kesalahan dan ketidakcermatan dalam menyusun daftar pustaka sebaiknya menggunakan aplikasi referensi, misalnya mendeley, zotero. Oleh karena itu dalam author guidelines pada Jurnal Pustaka Ilmiah ditambahkan dengan pernyataan berupa saran menggunakan aplikasi referensi, walaupun telah ada logo mendeley dalam interface jurnal.

\section{8) Statistik akses kunjungan yang tidak aktif}

Kualitas jurnal ilmiah dalam era elektronik ditentukan jumlah tingkat kunjungan unik pelanggan rerata per hari. Apabila sebuah jurnal tingkat kunjungan unik rerata per hari lebih dari 50 mendapat poin maksimal sebesar 4 dalam unsur evaluasi diri akreditasi jurnal nasional. Oleh karena itu menu statcounter Jurnal Pustaka Ilmiah diperbaiki sehingga tingkat kunjungan dapat diakses dan dipantau setiap saat. Tingkat kunjungan unik jurnal yang telah terindeks SINTA 2 dapat dijadikan sebagai acuan, misalnya Berkala Ilmu Perpustakaan dan Informasi dapat dilihat pada Gambar 10.

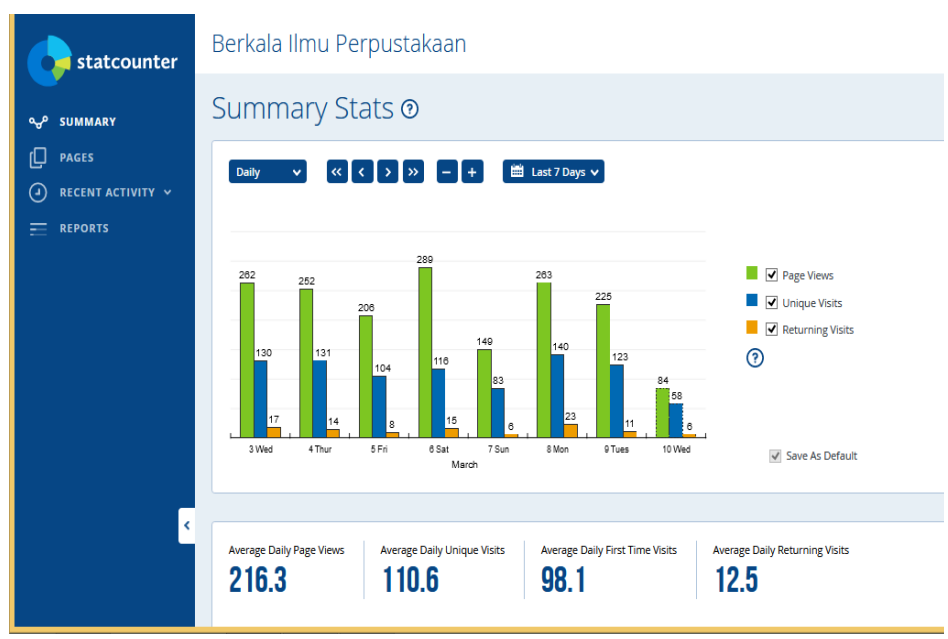

Gambar 10. Tampilan statcounter jurnal ilmiah terindeks SINTA 2

Sumber: https://journal.ugm.ac.id/v3/BIP/people (2021) 
9) Belum adanya informasi judul sirahan pada artikel yang diterbitkan Tolok ukur jurnal ilmiah yang berkualitas adalah konsisten dalam mutu penyuntingan gaya dan format. Artikel yang diterbitkan dilengkapi dengan judul sirahan yang informatif memuat nama jurnal, judul, volume, nomor, tahun, halaman, ISSN, dan alamat DOI. Oleh karena itu, Jurnal Pustaka Ilmiah sebaiknya artikel yang diterbitkan dilengkapi dengan judul sirahan. Judul sirahan yang sesuai dengan platform jurnal dapat dilihat dalam Gambar 11 di Jurnal Berkala Ilmu Perpustakaan dan Informasi.

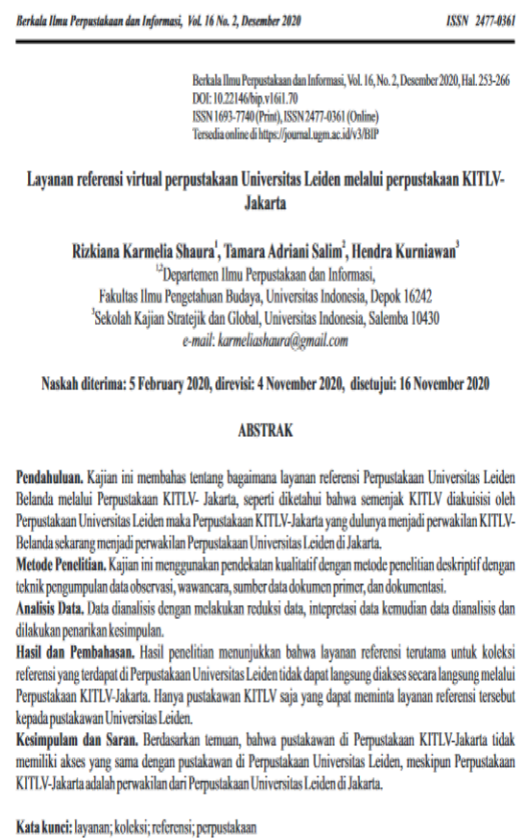

Gambar 11. Tampilan judul sirahan jurnal ilmiah terindeks SINTA 2 Sumber: https://journal.ugm.ac.id/v3/BIP/people (2021)

10) Sistem penomoran halaman masih melanjutkan volume sebelumnya Sistem penomoran halaman dalam jurnal ilmiah yang sesuai standar yaitu berurut dalam satu volume. Kesalahan yang sering terjadi dalam 
penomoran halaman di Jurnal Pustaka Ilmiah melanjutkan dari volume sebelumnya. Oleh karena itu Jurnal Pustaka Ilmiah dapat menyesuaikan sistem penomoran halaman sesuai standar yaitu penomoran awal jika ganti volume, seperti dapat dilihat di Gambar 12 pada Berkala Ilmu Perpustakaan dan Informasi.

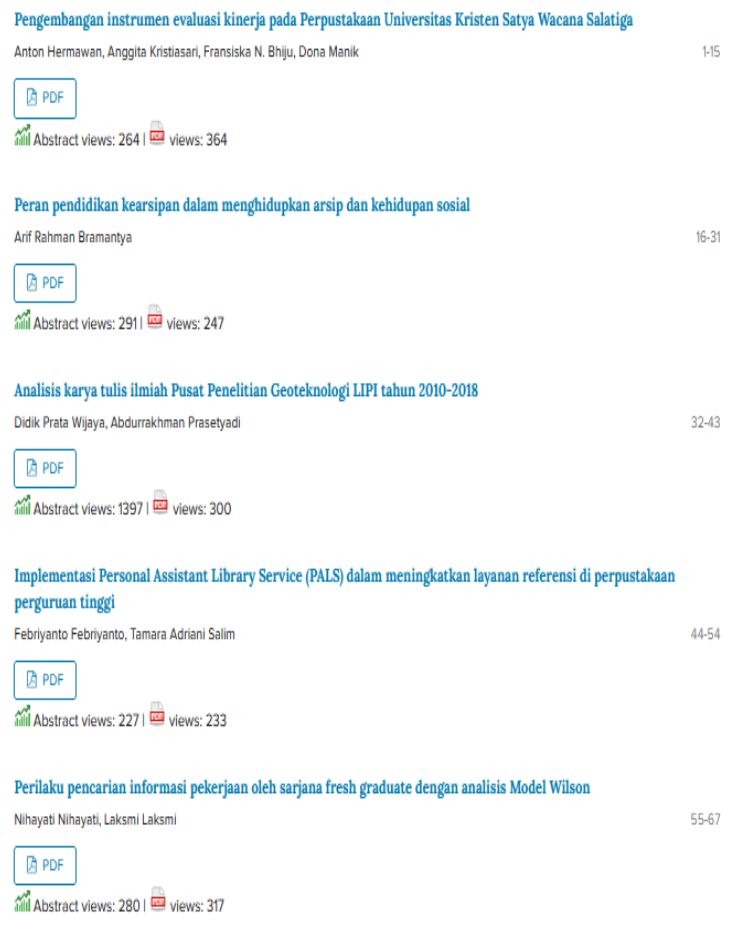

\section{Gambar 12. Tampilan sistem penomoran halaman jurnal ilmiah terindeks SINTA 2}

Sumber: https://journal.ugm.ac.id/v3/BIP/people (2021)

\section{1) Proses bisnis belum dijalankan dengan baik}

Tata kelola jurnal ilmiah secara elektronik berjalan transparan dan dapat dipantau setiap saat oleh penulis sejak proses submit naskah, review oleh editor, penelaahan naskah oleh mitra bestari, editing bahasa dan publish. 
Bukti kerja dari editor dan bukti review naskah oleh mitra bestari secara lengkap terekam dalam sistem secara kronologis. Bukti kerja editor dan reviewer merupakan salah satu faktor penilaian oleh asesor dalam tahapan akreditasi jurnal ilmiah. Oleh karena itu Jurnal Pustaka Ilmiah sebaiknya kelengkapan proses bisnis segera dilaksanakan untuk meningkatkan kualitas tata kelola jurnal ilmiah. Dalam pelaksanaan proses bisnis, perlu mendapat perhatian dari tim pengelola utamanya yang jurnal manager yang menguasai tata kelola jurnal yang baik dan benar.

\section{2)Dampak ilmiah atau sitasi di profil GS jurnal belum up to date}

Dampak ilmiah jurnal yaitu tingkat frekuensi artikel pada suatu jurnal ilmiah yang diacu atau disitasi oleh peneliti dalam melakukan penelitian selanjutnya. Dalam proses akreditasi jurnal ilmiah dampak ilmiah harus ditampilkan yang merupakan bukti rekaman jumlah sitasi oleh jurnal lainnya, faktor dampak, nilai $h$-index, dan pengakuan oleh lembaga pengindeks jurnal internasional. Dampak ilmiah dapat dilihat dari profil GS jurnal. Oleh karena itu, pengelola Jurnal Pustaka Ilmiah harus senantiasa meng-up date profil GS apabila setelah proses penerbitan nomor baru.

\section{3)Informasi terkait kebijakan review process belum dicantumkan}

Dalam tata kelola jurnal secara daring kebijakan terkait review process harus ditampilkan secara transparan. Standar review process digunakan sebagai pedoman bagi pengelola jurnal dalam proses penelaahan naskah diterima dari penulis. Disamping itu penulis juga mengetahui proses penelaahan naskah dilakukan sesuai standar tata kelola jurnal secara daring misalnya OJS. Oleh karena itu, pengelola Jurnal Pustaka Ilmiah segera untuk melengkapi informasi terkait kebijakan review process yang digunakan. Review process yang standar dapat mengacu pada jurnal yang telah terindeks SINTA 2 misalnya di Berkala Ilmu Perpustakaan dan Informasi seperti terlihat dalam Gambar 13. 


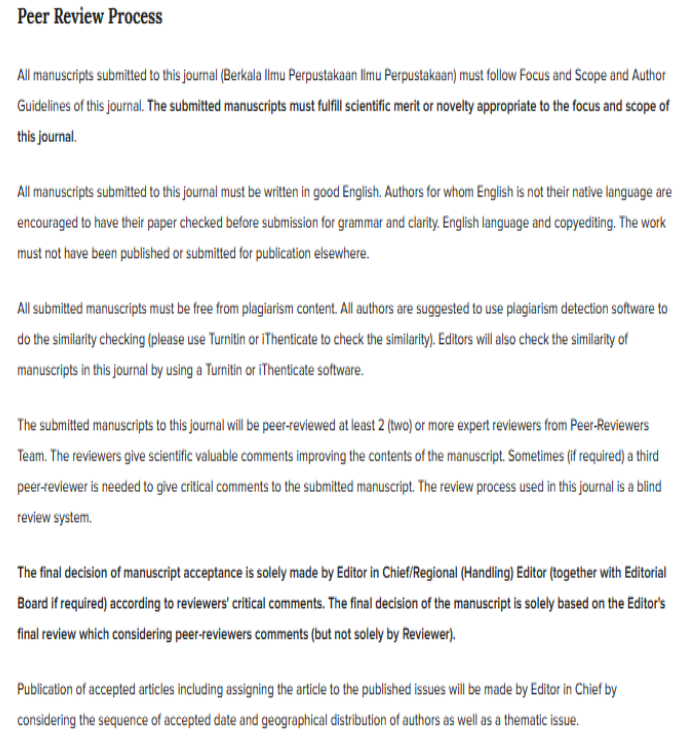

Gambar 13. Tampilan Review process jurnal ilmiah terindeks SINTA 2 Sumber: https://journal.ugm.ac.id/v3/BIP/Peer_Review_Process (2021)

\section{4) Keterangan distribusi afiliasi penulis belum dicantumkan}

Informasi afiliasi penulis dalam artikel yang dipublikasikan dalam jurnal ilmiah menunjukkan seberapa luas wawasan dari penyumbang artikel yang diterbitkan. Apabila luas wawasan semakin luas misalnya nasional, regional atau internasional akan mendapatkan poin yang sesuai dalam proses akreditasi nasional. Oleh karena itu, Jurnal Pustaka Ilmiah segera melengkapi informasi afiliasi penulis pada artikel yang diterbitkan. Tampilan afiliasi penulis juga mempermudah asesor menentukan jurnal tersebut termasuk jurnal lokal, nasional, ataupun internasional. Tampilan afiliasi yang sesuai dapat dilihat dalam gambar 14 pada artikel Berkala Ilmu Perpustakaan dan Informasi. 


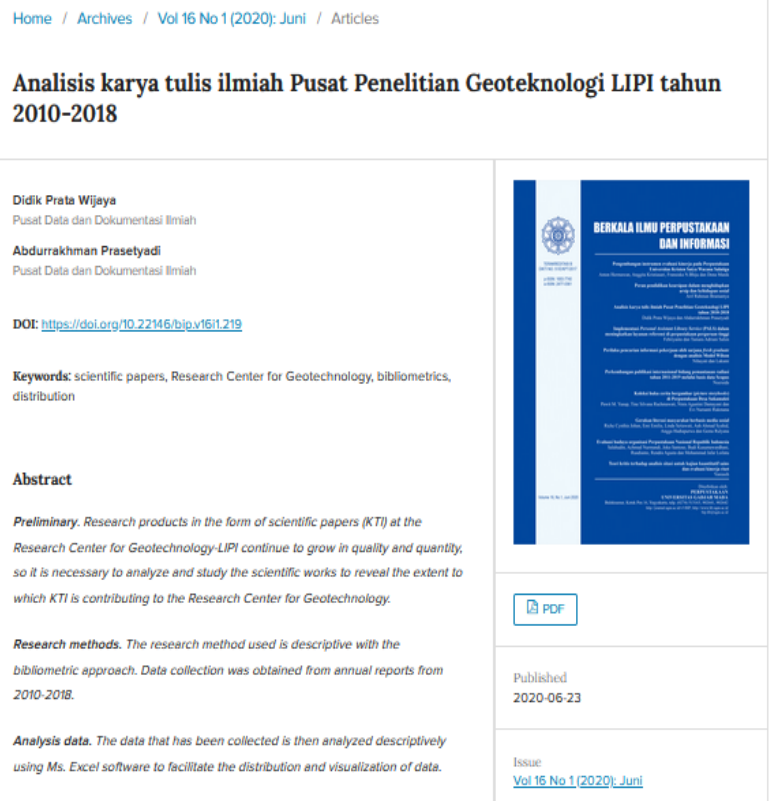

Gambar 14. Tampilan afiliasi penulis jurnal ilmiah terindeks SINTA 2 Sumber: https://journal.ugm.ac.id/v3/BIP/article/view/219 (2021)

Teknologi yang digunakan untuk transfer pengetahuan dalam tata kelola Jurnal Pustaka Ilmiah senantiasa mengikuti perkembangan teknologi. Mulai secara manual melalui pertemuan fisik, surat elektronik (email), aplikasi pesan instan seperti WhatsApp Group, sampai dengan teknologi online meeting. Teknologi yang dimaksud adalah teknologi synchronous dan asynchronous. Teknologi synchronous adalah teknologi yang memungkinkan dua belah pihak bisa berkomunikasi secara real time, sedangkan asynchronous adalah teknologi jarak jauh yang mungkin perlu waktu jeda untuk diberikan umpan balik (Fahmi, 2000). Teknologi synchronous diterapkan baik secara tatap muka maupun tidak. Teknologi synchronous yang dilakukan secara tatap muka merupakan teknologi fasilitas dari institusi seperti ruang rapat yang dilengkapi dengan $L C D$, internet, dan pada beberapa ruangan dilengkapi sarana komputer. Teknologi synchronous yang digunakan untuk komunikasi jarak jauh, seperti aplikasi online Zoom Meeting. Aplikasi ini 
digunakan secara synchronous, terutama pasca covid-19. Sebelum maraknya smart phone dan diterapkannya OJS, email adalah teknologi yang digunakan untuk berkomunikasi secara jarak jauh. Komunikasi via email dilakukan baik dengan sesama editor, reviewer, dan penulis. Saat ini aplikasi yang digunakan adalah instant messenger WhatsApp Group (WAG) untuk melakukan koordinasi Jurnal Pustaka Ilmiah. Dukungan dari instansi induk yakni universitas adalah melalui penyediaan infrastruktur teknologi, langganan zoom meeting, fasilitas email institusi, dan platform OJS. Dukungan universitas tidak hanya berwujud tangible saja, melainkan ada juga yang intangible. Universitas juga menyediakan semacam pembinaan bagi pengelola jurnal yang ada di seluruh universitas. Jurnal Pustaka Ilmiah telah diundang beberapa kali untuk mengikuti pembinaan tersebut. Pembelajaran organisasi menerapkan praktik baik untuk mencoba hal baru sangat bergantung pada pengelola. Beberapa contoh pertimbangan tersebut antara lain transisi Jurnal Pustaka Ilmiah dari manual ke OJS. Penyediaan OJS yang sudah berjalan tetapi belum diimplementasikan secara optimal. Hal tersebut terjadi karena minimnya SDM yang kompeten serta keberanian untuk mencoba hal baru. Pengelola Jurnal Pustaka Ilmiah segera melakukan tindak lanjut perbaikan dan tampilan seperti telah diuraikan dalam pembahasan yang mencakup dalam hasil rekomendasi assessment.

Berdasarkan uraian praktik-praktik manajemen pengetahuan yang dijelaskan, maka hal yang berperan utama dalam meningkatkan kesadaran berbagi pengetahuan terkait tata kelola Jurnal Pustaka Ilmiah adalah manajemen yang profesional. Manajemen yang sedemikian rupa diperlukan untuk menunjang keberhasilan transfer pengetahuan. Manajemen yang bergantung pada tokoh tertentu sangat rentan hancur ketika regenerasi. Kunci utama manajemen adalah memberikan kepercayaan kepada pihak pengelola, di sisi lain pihak pengelola juga perlu senantiasa memberikan laporan mengenai perjalanan pengelolaannya. Manajemen professional memerlukan partisipasi dan dukungan institusi induk melalui dengan kejelasan tugas, tanggungjawab, dan apresiasi untuk personil yang ditunjuk. 


\section{KESIMPULAN}

Transfer pengetahuan menjadi kunci keberhasilan pengelolaan jurnal, mulai dari awal pendiriannya sampai dengan saat ini. SDM yang cukup tetapi tanpa ada upaya transfer pengetahuan akan menjadi tidak optimal dalam kinerjanya, Tim Manajemen Perpustakaan UNS berupaya membangun sumberdaya manusia di bidang transfer pengetahuan pengelolaan jurnal ilmiah melalui jalur non formal dengan konsep diskusi ilmiah secara intensif dengan tenaga ahli yang kompeten di bidang Jurnal Ilmiah seperti yang telah dilaksanakan dengan tenaga ahli dari Jurnal "Berkala Ilmu Perpustakaan dan Informasi” Universitas Gadjah Mada. Hal ini membuat Jurnal Pustaka Ilmiah bisa tetap eksis dan berkembang jurnal ilmiah yang terakreditasi di masa mendatang. Salah satu hal utama dukungan majamen terhadap pengelola menjadi lebih termotivasi untuk melakukan berbagi pengetahuan dan berani mencoba hal baru untuk peningkatan kualitas tata kelola jurnal. Keberhasilan proses transfer pengetahuan bukan keberhasilan pengelola jurnal semata, melainkan perlu mendapatkan dukungan dari berbagai elemen. Dukungan yang berkelanjutan berimplikasi pada terciptanya manajemen profesional. Manajemen yang berkualitas akan mewujudkan tata kelola jurnal yang handal dan solid. Selain itu juga berdampak kepada pembaca dan penulis percaya pada Jurnal Pustaka Ilmiah sebagai salah satu sumber rujukan bidang Ilmu Perpustakaan dan Informasi terbaik di Indonesia.

\section{DAFTAR PUSTAKA}

Fahmi, Muhammad Hanif. 2020. "Komunikasi Synchronous dan Asynchronous Dalam E-Learning pada Masa Pandemic COVID-19”. Jurnal Nomosleca, 6(2), 146-158. https://jurnal.unmer.ac.id/index. $\mathrm{php} / \mathrm{n} /$ article/viewFile/4947/2596

Fathurrahmi, Destina \& Kusumaningrum, Retno. 2016. "Manajemen Pengetahuan Jurnal Ilmiah Berbasis Ontologi pada Portal Web Semantik". Skripsi, Universitas Diponegoro. http://eprints.undip. ac.id/59237/1/laporan_24010310120024_1.pdf 
Junandi, Sri. 2018. “Pengelolaan Jurnal Elektronik Bidang Perpustakaan Menuju Jurnal Terakreditasi”. Pustabiblia: Journal of Library and Information Science, 2(1), 119-136. https://doi.org/10.18326/ pustabiblia.v2i1.119-136

Junandi, Sri \& Prabowo, Thoriq Tri. 2019. “Kompetensi Pustakawan dalam Tata Kelola Jurnal Elektronik”. Media Informasi, 28(2), 187-200.

Kementerian Riset, Teknologi, dan Pendidikan Tinggi. 2018. "Permen Ristekdikti No. 9 Tahun 2018 tentang Akreditasi Jurnal Ilmiah". Kementerian Riset, Teknologi, dan Pendidikan Tinggi. https:// peraturan.bpk.go.id/Home/Details/140402/permen-ristekdikti-no9-tahun-2018

Nashihuddin, Wahid \& Aulianto, Dwi Ridlo. 2016. “Pengelolaan Terbitan Berkala Ilmiah Sesuai Ketentuan Akreditasi: Upaya Menuju Jurnal Terakreditasi dan Bereputasi Internasional". Jurnal Pustakawan Indonesia, 15(1-2), 83-98. https://doi.org/10.29244/jpi.v15i1-2.16921

Ningsih, Endang Retno. 2013. "Knowlegde Management System (KMS) dalam meningkatkan inovasi LPPM perguruan tinggi”. Evolusi, 1(1), 76-85. https://doi.org/10.31294/evolusi.v1i1.619

Prabowo, Thoriq Tri. 2016. "Implementasi Manajemen Pengetahuan di Perpustakaan UIN Sunan Kalijaga Yogyakarta”. Jurnal Kajian Informasi dan Perpustakaan, 4(2), 161. https://doi.org/10.24198/jkip. v4i2.9970

Prabowo, Thoriq Tri. 2019. "Komunikasi Efektif pada Bahasa Tubuh Pustakawan”. Khizanah al-Hikmah: Jurnal Ilmu Perpustakaan, Informasi, dan Kearsipan, 7(1), 1-10. https://doi.org/10.24252/kah. v7ila1

Prabowo, Thoriq Tri. 2020. "Penerapan Manajemen Pengetahuan dalam Pengelolaan Dokumen di Perpustakaan STIKes Guna Bangsa”. Khazanah: Jurnal Pengembangan Kearsipan, 13(1), 17-33. https:// doi.org/10.22146/khazanah.53067

Praharsi, Yugowati. 2016. "Manajemen Pengetahuan dan Implementasinya 
dalam Organisasi dan Perorangan”. Jurnal Manajemen Maranatha, 16(1), 77-90. https://doi.org/10.28932/jmm.v16i1.7

Public Knowledge Project. 2020. "Public Knowledge Project”. OJS Editorial and Publishing Process. https://pkp.sfu.ca/

Saputra, Andi. 2020. "Memanfaatkan SINTA (Science and Technology Index) Untuk Publikasi Karya Ilmiah \& Strategi Dalam Mencari dan Memilih Jurnal Nasional Terakreditasi”. Media Pustakawan, 27(1), 56-68. https://doi.org/10.37014/medpus.v27i1.674

Utami, Ni Putu Pramita. 2019. "Perilaku Knowledge Sharing antar staf pustakawan: Suatu Kajian melalui Pendekatan Learning Audit Model pada Perpustakaan Universitas Pendidikan Ganesha”. Media Pustakawan, 26(3), 184-198. https://doi.org/10.37014/medpus. v26i3.544

Widuri, Noorika Retno. 2015. "Komunikasi Nonverbal Sebagai Upaya Optimalisasi Layanan Perpustakaan”. Media Pustakawan, 22(2), 6-11. https://doi.org/10.37014/medpus.v22i2.820

Wiratningsih, Riah. 2014. "Knowledge Management: Implementasi Peran Pustakawan dalam Menghadapi AFTA 2015”. Fihris, 9(2), 23-40. 